\title{
Changes in Imja Lake and Karda Lake in the Everest Region of Himalaya
}

\author{
Wenbo Chen ${ }^{1 *}$, Tomoko Doko ${ }^{2,3}$, Hiromichi Fukui ${ }^{4}$, Wanglin Yan ${ }^{1}$ \\ ${ }^{1}$ Graduate School of Media and Governance, Keio University, Fujisawa, Japan; ${ }^{2}$ Research Institute of Environment and Information \\ Sciences, Yokohama National University, Yokohama, Japan; ${ }^{3}$ Research Fellow of the Japan Society for the Promotion of Science, \\ Tokyo, Japan; ${ }^{4}$ Chubu Institute for Advanced Studies, Chubu University, Kasugai, Japan. \\ Email: ${ }^{*}$ chenwb@sfc.keio.ac.jp
}

Received August 24 $4^{\text {th }}, 2013$; revised September 27 $7^{\text {th }}, 2013$; accepted October $12^{\text {th }}, 2013$

Copyright (C) 2013 Wenbo Chen et al. This is an open access article distributed under the Creative Commons Attribution License, which permits unrestricted use, distribution, and reproduction in any medium, provided the original work is properly cited.

\begin{abstract}
The Himalaya is a region sensitive to climate change. Changes in the glacial regime are one indicator of global climate changes. There are several studies focusing on analysis of temporal changes of these glacial lakes in the Himalaya region. However, the researches on addressing these trends in relation with surrounding topographical conditions are quite limited. In this study, we analyzed spatio-temporal changes in Imja Lake, located on the southern slope, and Karda Lake, located on the northern slope of the Mt. Everest region, in 1976, 1992, 2000, and 2008. Moreover, we examined whether the topographic conditions differ between the two slopes. Landsat and ASTER GDEM (advanced space borne thermal emission and reflection radiometer, global digital elevation model) data were used to identify boundaries of target glacial lakes and to calculate three indices of growth rate compared to year of $1976\left(\%, G R_{a}\right)$, growth rate compared to preceding year $\left(\%, G R_{b}\right)$, and growth speed $\left(\mathrm{m}^{2} /\right.$ year, GS) of the two lakes. The topographic conditions in circular buffer zones from the centroid of the two lakes were analyzed. Although the area of two lakes demonstrated linear increase from 1976 to 2008, growth rate compared to year of $1976\left(G R_{a}\right)$ differed significantly (Kruskal-Wallis test, $p<$ 0.05). The area of Imja Lake enlarged significantly faster than the one of Karda Lake (Kruskal-Wallis test and Chisquared test for independence on $m \times n$ contingency table between 1976, 1992, 2000, and 2008 on growth speed (GS)). The two slopes differed in terms of three topographical variables: altitude, aspect, and angle of inclination (KruskalWallis test, $p<0.05)$. The differences between the growth trends of the two lakes can be explained by differences in the topographic conditions on their respective slopes. However, differences in temporal changes should be explained by other temporal factors, e.g. climatic variables.
\end{abstract}

Keywords: Glacial Lakes; Topography; Himalaya; Remote Sensing; GIS

\section{Introduction}

The Himalaya is well known for its high altitude, frigid temperatures, high wind speeds, thin air, and remoteness. The physiography of the Himalaya is characterized by a complex network of mountains and valleys [1]. Sharp ridge crests and deep valleys are its main characteristics [1]. These characteristics may influence changes in its glacial regime.

Since the last century, most Himalayan glaciers have melted at a rate that ranges from a few meters to several tens of meters per year [2]. These changes directly affected the formation and enlargement of downstream

${ }^{*}$ Corresponding author. glacial lakes, often resulting in a glacial lake outburst flood (GLOF) [3-8]. Thus, identifying and monitoring changes in glacial lakes become important in understanding of the regional environment and local ecosystems.

Several studies have focused on the trend of growing glacial lakes in the Himalaya region. However, few of the studies address these trends in a context of the surrounding topographic conditions of the target lakes.

The objectives of this study were (a) to analyze spatio-temporal differences in the trends of changes in Imja Lake, located on the southern slope, and Karda Lake, located on the northern slope of the Himalayan range during four time periods, i.e., 1976, 1992, 2000, and 2008 and (b) to examine whether the topographic condi- 
tions differ between the northern and southern slopes of the Mt. Everest region.

\section{Methods}

\subsection{Study Area}

The study area is located in the Mt. Everest region, Himalayan range. The northern slope is located in China, and the southern slope is located in Nepal (see Figure 1). The target glacial lakes are Karda Lake, located on the northern slope, and Imja Lake, located on the southern slope.

Karda Lake is located in Tibet, China, on the northern slope of Mt. Everest. The altitude of Karda Lake is 5,643 $\mathrm{m}$; the latitude and longitude are $28^{\circ} 4.28^{\prime}$ and $87^{\circ} 3^{\prime}$, respectively. Karda Lake is a moraine lake, which was a smaller pond at the snout of Karda Glacier in 1925 [9]. Accessing Karda Lake is extremely difficult, and hence previous studies of Karda Lake are limited. The year when Karda Lake started to expand is not known.

Imja Lake (lat./long. $27^{\circ} 4^{\prime} / 86^{\circ} 5.4^{\prime}$, altitude $5010 \mathrm{~m}$ ) is located in the Dudh Koshi Basin of Nepal, on the southern slope of Mt. Everest. Imja Lake did not exist in the early 1960s [2]. Instead, only several smaller supraglacial ponds were present in this location. Imja Lake began growing in 1975 due to glacial melting. Its surface area expanded from $0.30 \mathrm{~km}^{2}$ in 1975 to $0.85 \mathrm{~km}^{2}$ in 2000 [2]. It has been identified as one of the lakes displaying the greatest potential for a GLOF now in the Nepalese part of the Himalaya [10]. Imja Lake has been relatively studied as it is easier to access and it is concerned due to its faster expansion.

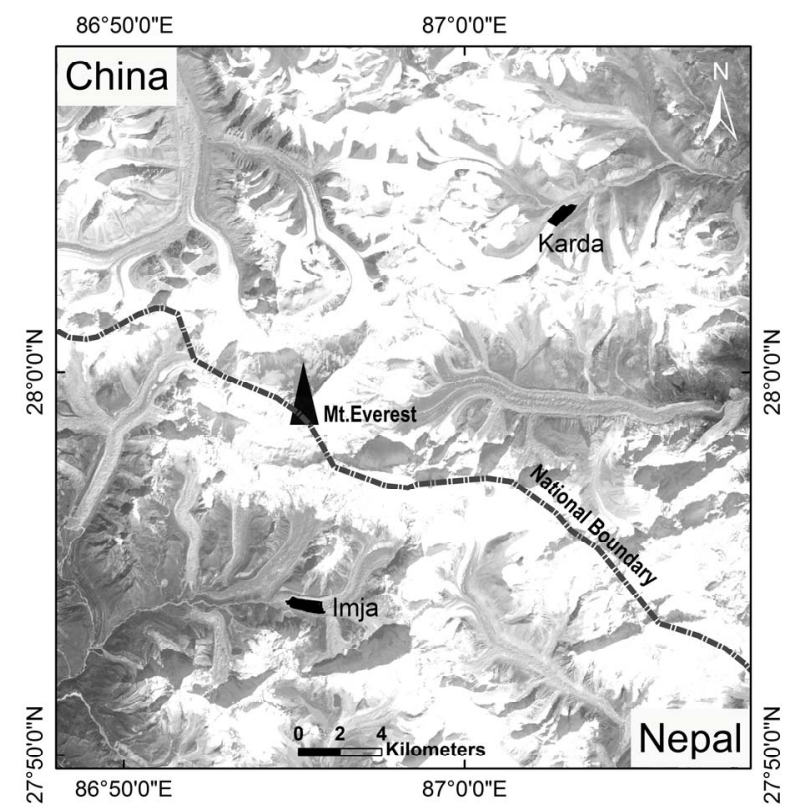

Figure 1. Study area.

\subsection{Data Sources}

Satellite images with minimal obstruction by clouds and snow coverage were used in this study. These images were from the Landsat MSS from December 1976, with a spatial resolution of $60 \mathrm{~m}$, the Landsat TM from November 1992, with a spatial resolution of $30 \mathrm{~m}$, the Landsat $\mathrm{ETM}+$ from October 2000, with a spatial resolution of $30 \mathrm{~m}$, and the ASTER from January 2008, with a spatial resolution of $15 \mathrm{~m}$. For the terrain analysis, ASTER Global DEM data were downloaded from the ASTER GDEM website.

\subsection{Identification of Glacial Lakes}

Figure 2 presents the flowchart of the study. First, the NDWI (normalized difference water index) was calculated to allow identification of water bodies from the Landsat satellite images. NDWI is defined as the difference of reflectance observed in the green band and the NIR band divided by the sum of the two reflectance values [11]. The value of this index ranges from -1 to +1 .

Second, a model of the terrain was developed from a digital elevation model (DEM) derived from the ASTER GDEM data. Based on our previous field work in the Himalaya and Tibet, China, it was recognized that the angle of inclination that allowed drainage of melt water had gradients greater than $10^{\circ}$. Study in Bhutan [12] and study in China and Nepal [13] reported similar observations. Thus, a threshold value of a ground angle of inclination of $10^{\circ}$ (maximum) was adopted in this study.

Finally, the boundaries of two glacial lakes were identified by integrating the NDWI and angle of inclination criteria. The satellite imagery analysis and data processing were performed using ENVI ${ }^{\circledR} 4.7$.

\subsection{Trends of Changes in the Two Glacial Lakes}

First, the surface areas of Imja Lake and Karda Lake during the four time periods in the years 1976, 1992, 2000, and 2008 were calculated in $\mathrm{m}^{2}$ and coded as $A_{\text {lake.year }}$. The variable lake was coded as either "Imja" or "Karda", and the year was coded as 1976, 1992, 2000, or 2008. For example, $A_{\text {Imja.1976 denotes the surface area of Imja }}$ Lake in 1976.

Second, based on the surface areas of the glacial lakes, three indices were developed: 1) the growth rate of the area of a particular lake compared to its area in 1976 was defined as $G R_{\text {a.lake.year }}(\%)$, for example, $G R_{\text {a.Imja.1992 }}=$ $A_{\text {Imja.1992 }} / A_{\text {Imja.1976 }} * 100$, whereas $G R_{\text {a.Imja.1976 }}=100 ; 2$ ) the growth rate of the area of a lake compared to that of the lake in the preceding time interval was defined as $G R_{\text {b.lake.year }}(\%)$, for example, $G R_{\text {b.Imja.2008 }}=A_{\text {Imja.2008 }} /$ $A_{\text {Imja.2000 }} * 100$; and 3 ) the growth speed of a lake was defined as the expanded area per year between consecutive time periods and was coded as $G S_{\text {lake.year }}\left(\mathrm{m}^{2} /\right.$ year), 


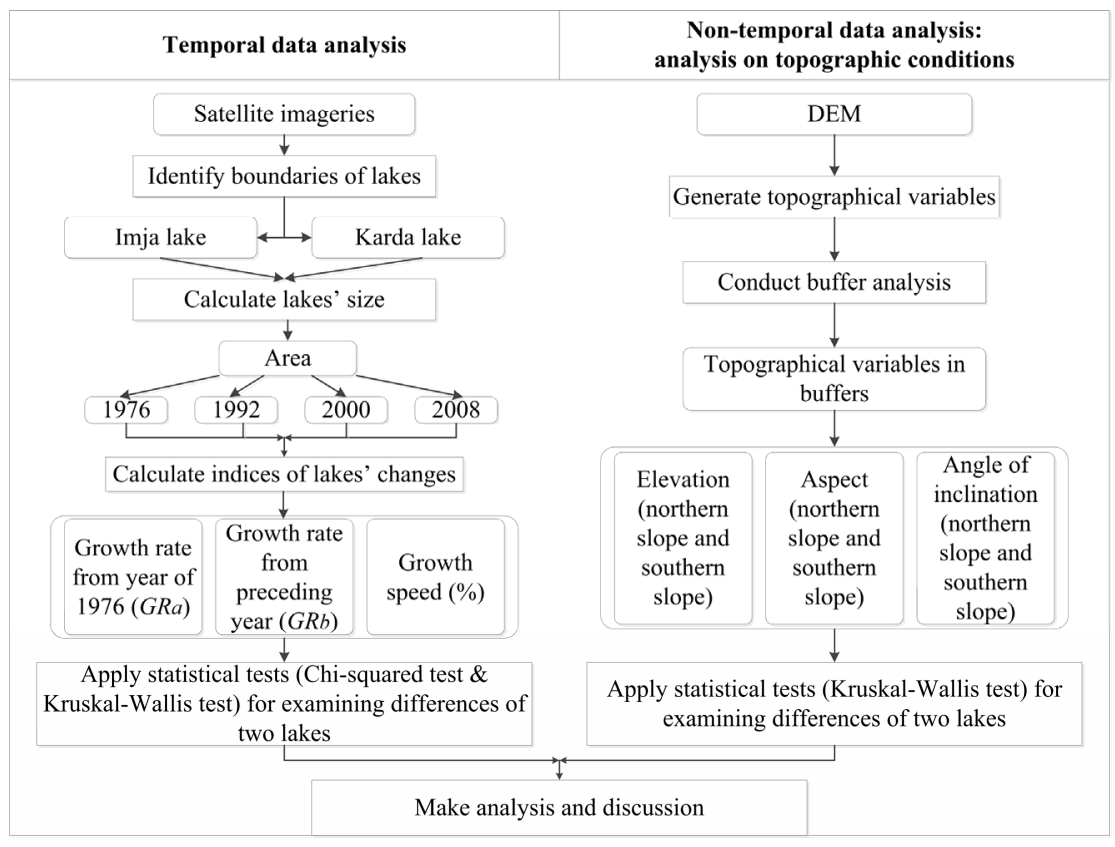

Figure 2. Flowchart of the method.

for example, $G S_{\text {Imja.2008 }}=\left(A_{\text {Imja.2008 }}-A_{\text {Imja.2000 }}\right) /(2008-$ 2000).

Third, the trends of changes in the two glacial lakes were analyzed using a bar chart and a line chart. For comparison purposes, the data were aggregated in 8-year time intervals. Because the interval from 1976 to 1992 spanned 16 years, the surface area in 1984 was interpolated to the mean value between 1976 and 1992, defined as $A_{\text {lake.1976 }}+\left(A_{\text {lake.1992 }}-A_{\text {lake.1976 }}\right) / 2$.

Fourth, two statistical tests were applied. The Kruskal-Wallis test was applied to examine if there is a significant difference $(p<0.05)$ between the two lakes regarding the three indices, $G R_{\text {a.lake.year }}(\%), G R_{\text {b.lake.year }}(\%)$, and $G S_{\text {lake.year }}\left(\mathrm{m}^{2} /\right.$ year). The Chi-squared test for independence on an $m \times n$ contingency table was applied to test for independence between the time periods and the two lakes regarding the three indices $(p<0.05)$. These statistical analyses were conducted using Microsoft Excel 2010.

\subsection{Topographic Conditions on Northern and Southern Slopes}

We hypothesized that the changes in the two lakes are influenced by their positions on the two different slopes (northern slopes and southern slopes) of the Mt. Everest region. To address the potential differences in topographic conditions between the two lakes, three topographical variables, which are their altitude, angle of inclination, and aspect, were calculated. First, the distance from the centroid of a lake to the international boundary was calculated using ArcMap ver. $10^{\circledR}$. The international boundary between China and Nepal was assumed to represent the crest of the mountain range in this study. The lake closest to this boundary was Imja Lake, which is located $6.7 \mathrm{~km}$ from the boundary. Second, a buffer zone around the centroid point of a target lake was generated for each lake, using a radius of $6.7 \mathrm{~km}$. Finally, the topographical variables inside the buffers around the two lakes were evaluated based on the ASTER GDEM data using ArcMap ver. $10^{\circledR}$. The slope aspect was measured clockwise in degrees from azimuth 0 , due north, to 360 , again due north, coming full circle. The value of each cell in an aspect dataset indicates the direction of the cell's slope face. Level areas having no downslope direction were given a value of -1 .

The distribution of the three topographical variables was examined using histograms. Descriptive statistics were calculated for each variable. The topographical differences between northern and southern slopes were tested using the Kruskal-Wallis test $(p<0.05)$. These statistical analyses were conducted using the software R, version 2.13.2.

\section{Results}

\subsection{Trends of Changes in the Two Glacial Lakes}

Map comparison during the 32 years showed that both Imja Lake and Karda Lake were generally increasing (see Figure 3). The surface areas $\left(\mathrm{m}^{2}\right)$ of the two glacial lakes in 1976, 1992, 2000, and 2008 are summarized in Table 1. The surface area of Imja Lake expanded by $574,104 \mathrm{~m}^{2}$ from 1976 to 2008 , and the surface area of Karda Lake expanded by $287,957 \mathrm{~m}^{2}$. 


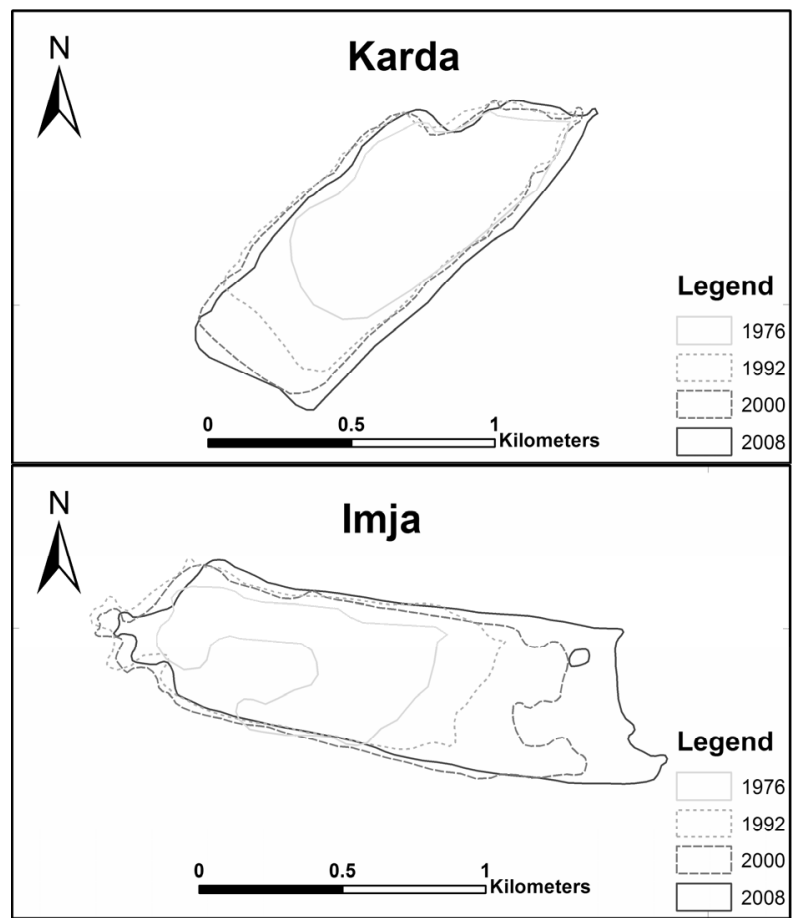

Figure 3. Changes in Imja and Karda Lakes.

The trends of the changes in the two glacial lakes were plotted with regard to the growth rate (Figure 4) and growth speed (Figure 5). The growth rate compared to year of 1976 (GR a.lake.year $)$ of both lakes displayed linear increases beginning in 1976 (Figure 4; line chart). However, the growth rate compared to preceding year of both lakes, $G R_{\text {b.lake.year }}(\%)$ (Figure 4; bar chart), displayed downward trends over time. The growth speed, $G S_{\text {lake.year }}$ $\left(\mathrm{m}^{2} /\right.$ year), of both lakes declined over time (Figure 5$)$.

Table 2 shows results of statistical tests to examine differences between Imja Lake and Karda Lake. The Kruskal-Wallis test revealed a significant difference $(p<$ $0.05)$ between the two lakes regarding the $G R_{\text {a.lake.year }}$ in$\operatorname{dex}(\% ; T=3.85, f=1)$ and the $G S_{\text {lake.year }}$ index $\left(\mathrm{m}^{2} /\right.$ year; $T=3.85, f=1)$ but not regarding the $G R_{\text {b.lake.year }}$ index $(\%$; $T=1.19, f=1)$. On the other hand, the Chi-squared test for independence on the $m \times n$ contingency table $(p<$ 0.05 ) demonstrated a relationship between the time periods and $G S_{\text {lake.year }}\left(\mathrm{m}^{2} /\right.$ year; $T=349.82, f=2, m=2, n=$ 3 ) index but none between the time periods and the $G R_{\text {alake.year }}(\% ; T=2.03, f=2, m=2, n=3)$ nor $G R_{\text {blake.year }}(\% ; T=2.81, f=2, m=2, n=3)$ indices.

\subsection{Topographic Conditions of Different Slopes}

Table 3 presents descriptive statistics of the topography (aspect, angle of inclination, and altitude). Figure 6 presents the values of these three variables in histogram form. The findings indicate that the northern slope had a mean southeast aspect (154.3 degrees), whereas the
Table 1. Changes in lake surface area.

\begin{tabular}{ccc}
\hline Area $\left(\mathbf{m}^{\mathbf{2}}\right)$ Year & Imja Lake & Karda Lake \\
\hline 1976 & 284,411 & 389,317 \\
1992 & 567,360 & 550,732 \\
2000 & 724,365 & 623,236 \\
2008 & 858,515 & 677,274 \\
\hline
\end{tabular}

southern slope had a southwest aspect (194.1 degrees). Although the mean altitude of the southern slope $(5,530$ $\mathrm{m})$ was lower than that of the northern slope $(5,878 \mathrm{~m})$, its angle of inclination was steeper (mean angle of inclination $=27.3$ degrees) than that of the northern slope (mean angle of inclination $=19.8$ degrees).

There were significant topographical differences (Kruskal-Wallis test, $p<0.05, d f=1)$ between the northern and southern slopes with regard to their aspect (KruskalWallis chi-squared $=14622.1, p<2.2 \mathrm{e}-16$ ), altitude (Kruskal-Wallis chi-squared $=66969.65, p<2.2 \mathrm{e}-16$ ), and angle of inclination (Kruskal-Wallis chi-squared = $14639.19, p<2.2 \mathrm{e}-16)$.

\section{Discussion}

Our statistical analysis (Figures 4 and 5, Table 2, Kruskal-Wallis test) revealed significant differences between the two lakes in terms of their growth rates, $G R_{\text {allake.year }}$ $(\%)$, and growth speed, $G S_{\text {lake.year }}\left(\mathrm{m}^{2} /\right.$ year). There was no difference between the growth rate compared to preceding year, $G R_{\text {b.lakeyear }}(\%)$, of the two lakes. Although the two lakes exhibited a linear trend of enlargement from 1976 to 2008, their rates of growth differed significantly. The growth rate of Imja Lake was much greater than that of Karda Lake. On the other hand, their rates of expansion displayed a downward trend over time. The recent changes, i.e., between 2000 and 2008, were smaller than those between 1976 and 1984. These downward trends were consistent in both of the lakes.

The differences between Imja Lake and Karda Lake can be explained by differences in the topographic conditions between the southern and northern slopes. Our spatial buffer analysis and statistical analysis revealed that the northern and southern slopes differ with regard to the three topographical variables of altitude, aspect, and angle of inclination (Figure 6, Tables 2 and 3, KruskalWallis test). The difference in altitude is considered to have influenced the development of the glacial lakes. Generally, the temperature decreases $0.65^{\circ} \mathrm{C}$ per $100 \mathrm{~m}$ of elevation increase in the high mountains. This generalization implies that the environment of Karda Lake is colder than that of Imja Lake. Second, the difference in aspect affects the level of solar heating. Heating is greatest on southwest-aspect slopes [14], which may cause 


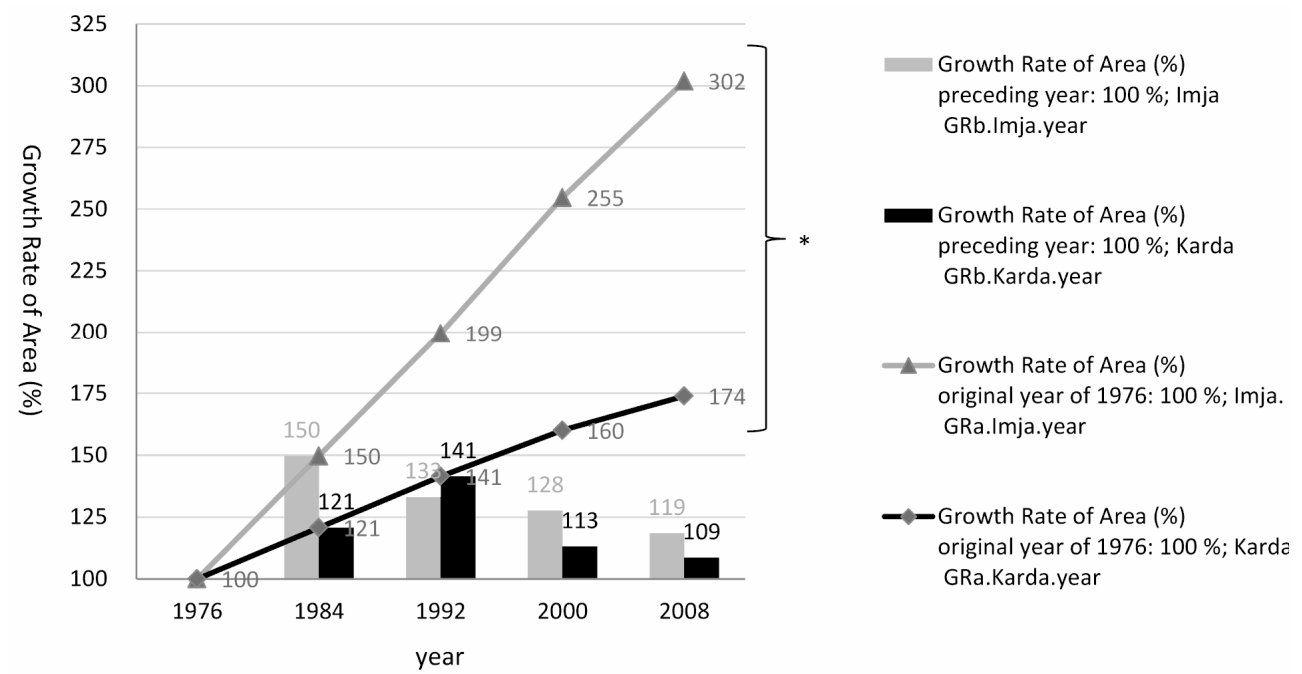

Figure 4. Trends in growth rates of lake surface area.

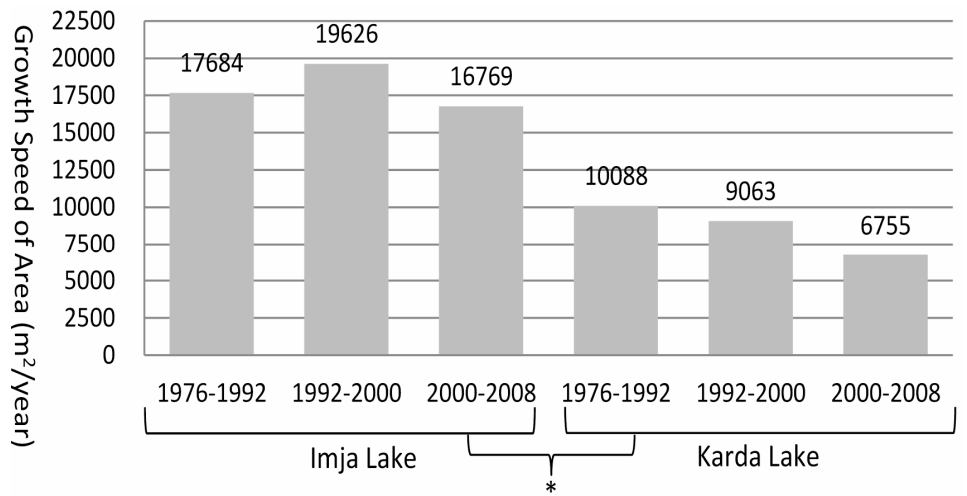

Figure 5. Trends in growth speed of lake surface area.

Table 2. Results of statistical tests to examine differences between Imja Lake and Karda Lake.

(A) Temporal data analysis

\begin{tabular}{|c|c|c|}
\hline & $\begin{array}{l}\text { Kruskal-Wallis test for } \\
\text { a whole time period }\end{array}$ & $\begin{array}{l}\text { Chi-squared test for independence on } m \times n \\
\text { contingency table between } 1976,1992,2000 \text {, and } 2008\end{array}$ \\
\hline Growth rate compared to year of $1976\left(G R_{a}\right)$ & $T=3.85, f=1^{*}$ & $T=2.03, f=2, m=2, n=3$ (No difference) \\
\hline Growth rate compared to preceding year $\left(G R_{b}\right)$ & $\begin{array}{l}T=1.19, f=1 \\
\text { (No difference) }\end{array}$ & $T=2.81, f=2, m=2, n=3($ No difference) \\
\hline Growth speed (GS) & $T=3.85, f=1^{*}$ & $T=349.82, f=2, m=2, n=3^{*}$ \\
\hline
\end{tabular}

(B) Non-temporal data analysis: analysis on topographic conditions

\begin{tabular}{cccc}
\hline & \multicolumn{2}{c}{ Kruskal-Wallis test } & Angle of inclination \\
\cline { 2 - 4 } Imja Lake & $\begin{array}{c}\text { Altitude } \\
\text { Kruskal-Wallis chi-squared } \\
\text { Karda Lake }\end{array}$ & $\begin{array}{c}\text { Kruskal-Wallis chi-squared } \\
=14622.1, p<2.2 \mathrm{e}-16^{*}\end{array}$ & Kruskal-Wallis chi-squared $=14639.19, p<2.2 \mathrm{e}-16^{*}$ \\
\hline
\end{tabular}

Note. ${ }^{*}$ means there is a significant difference between two lakes $(p<0.05)$. 
Table 3. Summary of aspect, angle of inclination, and altitude.

\begin{tabular}{|c|c|c|c|}
\hline \multicolumn{2}{|c|}{ Slope Parameter } & North & South \\
\hline \multirow{4}{*}{ Aspect (degree) } & Min & -1 & -1 \\
\hline & Mean & 154.3 & 194.1 \\
\hline & Max & 359.8 & 359.9 \\
\hline & SD & 101.28 & 93.99 \\
\hline \multirow{4}{*}{ Angle of inclination (degree) } & Min & 0 & 0 \\
\hline & Mean & 19.8 & 27.3 \\
\hline & Max & 68.54 & 81.47 \\
\hline & SD & 11.64 & 17.07 \\
\hline \multirow{4}{*}{ Altitude (m) } & Min & 5102 & 4522 \\
\hline & Mean & 5878 & 5530 \\
\hline & Max & 7173 & 7930 \\
\hline & SD & 283.72 & 526.43 \\
\hline
\end{tabular}
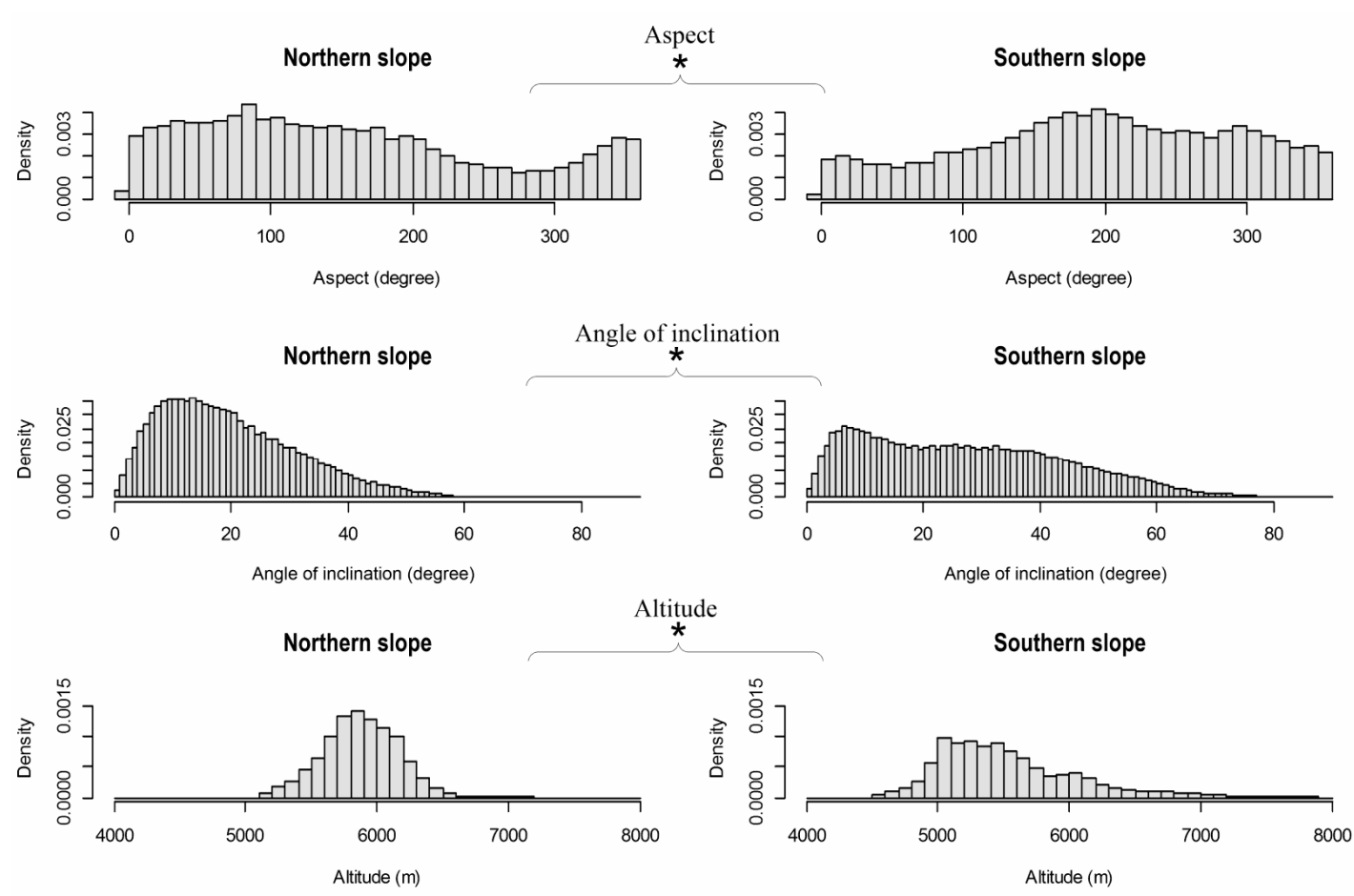

Figure 6. Aspect, angle of inclination, and altitude on northern and southern slopes.

Imja Lake (southwest aspect) to receive greater heating than Karda Lake (southeast aspect). Third, the southern slope is steeper than the northern slope. This difference in angle of inclination may cause glacial melt water to concentrate and accumulate in relatively level areas downstream. Finally, because the windward side of the mountain range may receive more air moisture than the leeward side $[15,16]$, the southern slope may receive more precipitation than the northern slope. The interaction between all of these factors is considered to cause the difference in the growth trends of the two glacial lakes.

On the other hand, our statistical analysis of the temporal changes during the four time periods in the years 1976, 1992, 2000, and 2008 (Chi-squared test) revealed a relationship between the time periods and growth speed (Table 2). These phenomena cannot be explained by changes in topographic conditions on the northern and southern slopes because the topographic conditions are usually stable over time. To address this issue, environmental variables that are affected by temporal changes should be considered. We assume that climatic variables 
could explain the temporal changes of the rates of expansion of these two lakes. Available climatic data are currently quite rare because the extreme conditions in the Himalaya region make it extremely difficult to build meteorological stations there. Future studies require a climatic model to allow analysis of the temporal changes of the glacial lakes caused by climate variables.

\section{Acknowledgements}

The authors are thankful to the Global Earth Observation Grid, Japan, for providing the ASTER data via the GEO Grid project, which was developed with the goal of providing an E-Science infrastructure to the worldwide earth sciences community. Funding for this research was provided by the Research Promotion Fund in Remembrance of Mori Taikichiro in 2011, 2012, and 2013 of Keio University, and Kurita Water and Environment Foundation, in 2013 .

\section{REFERENCES}

[1] S. S. Negi, "Discovering the Himalaya," Indus Publishing Co., New Delhi, 1998.

[2] S. R. Bajracharya, P. K. Mool and B. R. Shrestha, "Impact of Climate Change on Himalayan Glaciers and Glacial Lakes: Case Studies on Glof and Associated Hazards in Nepal and Bhutan," International Centre for Integrated Mountain Development (ICIMOD), Kathmandu, 2007.

[3] D. A. Cenderelli and E. E. Wohl, "Peak Discharge Estimates of Glacial-Lake Outburst Floods and 'Normal' Climatic Floods in the Mount Everest Region, Nepal," Geomorphology, Vol. 40, No. 1-2, 2001, pp. 57-90. http://dx.doi.org/10.1016/S0169-555X(01)00037-X

[4] X. Chen, P. Cui, Z. Yang and Y. Qi, "Risk Assessment of Glacial Lake Outburst in the Poiqu River Basin of Tibet Autonomous Region," Journal of Glaciology and Geocryology, Vol. 29, No. 4, 2007, pp. 509-516.

[5] M. Ghimire, "Review of Studies on Glacier Lake Outburst Floods and Associated Vulnerability in the Himalayas," The Himalayan Review, Vol. 35/36, No. 2004/2005, 2009, pp. 49-64.

[6] R. Kattelmann, "Glacial Lake Outburst Floods in the Ne- pal Himalaya: A Manageable Hazard?" Natural Hazards, Vol. 28, No. 1, 2003, pp. 145-154.

http://dx.doi.org/10.1016/S0169-555X(01)00037-X

[7] D. Xu, "Characteristics of Debris Flow Caused by Outburst of Glacial Lake in Boqu River, Xizang, China, 1981," Glaciology Journal, Vol. 17, No. 4, 1988, pp. 569580. http://dx.doi.org/10.1007/BF00209443

[8] T. Yamada and C. K. Sharma, "Glacier Lakes and Outburst Floods in the Nepal Himalaya," In: G. J. Young, Ed., Snow and Glacier Hydrology, IAHS Publication, Kathmandu, 1993, pp. 319-330.

[9] J. Hemmleb, L. A. Johnson and E. R. Simonson, "Ghosts of Everest: The Authorised Story of the Search for Mallory \& Irvine," Pan, London, 1999.

[10] P. K. Mool, S. R. Bajracharya and S. P. Joshi, "Inventory of Glaciers, Glacial Lakes and Glacial Lake Outburst Floods-Monitoring and Early Warning Systems in the Hindu Kush-Himalayan Region, Nepal,' International Centre for Integrated Mountain Development (ICIMOD), Kathmandu, 2001.

[11] S. K. McFeeters, "The Use of the Normalized Difference Water Index (Ndwi) in the Delineation of Open Water Features," International Journal of Remote Sensing, Vol. 17, No. 7, 1996, pp. 1425-1432. http://dx.doi.org/10.1080/01431169608948714

[12] J. M. Reynolds, "On the Formation of Supraglacial Lakes on Debris-Covered Glaciers," Proceedings of International Association of Hydrological Sciences (IAHS), Seattle, Washington, 2000, pp. 153-161.

[13] D. J. Quincey, et al., "Early Recognition of Glacial Lake Hazards in the Himalaya Using Remote Sensing Datasets," Global and Planetary Change, Vol. 56, No. 1/2, 2007, pp. 137-152. http://dx.doi.org/10.1016/j.gloplacha.2006.07.013

[14] B. McCune and D. Keon, "Equations for Potential Annual Direct Incident Radiation and Heat Load," Journal of Vegetation Science, Vol. 13, No. 4, 2002, pp. 603-606. http://dx.doi.org/10.1111/j.1654-1103.2002.tb02087.x

[15] R. G. Barry, "Mountain Weather and Climate," 3rd Edition, Cambridge University Press, Cambridge, 2008. http://dx.doi.org/10.1017/CBO9780511754753

[16] M. P. Bishop and J. F. Shroder, "Geographic Information Science and Mountain Geomorphology," Springer \& Praxis Publishing, Chichester, 2004. 